\title{
FINANCIAL ADVICE AND GUIDANCE FOR SMALL BUSINESS
}

\author{
JOSEPH K. WEXMAN*
}

Nearly everyone who has had any experience with lending to the small businessman recognizes that the.average small borrower needs improved management quite as much as he needs financial aid. The typical experience of financial executives is reflected in the following comment by G. Harvey Porter, Director of the Industrial Corporation of Baltimore:

"Thirty years of experience of our corporation, dealing with hundreds of cases has convinced us that small business needs more counsel than cash. Small business will not agree to that. It is easier to cover up your shortcomings with new cash and to stay in your comfortable management rut than to correct your practices or vary your policyif you can get the cash; whereas, small business can many times effect more financing faster with a new policy, and sometimes personnel changes, than in any other manner."1

Many small businessmen have sensed their management limitations, have limited their operations accordingly, taking the attitude they don't want the headaches that go with business expansion. Even these could probably reduce their headaches within the limited sphere in which they operate by being initiated into some of the elementary principles of sound financial control and management.

For those who wish to expand, the enlargement of their financial responsibility makes imperative a better understanding of how to meet those responsibilities.

I

The small businessman would be the first to admit his confusion about problems related to finance. He must know about prospects of the industry, general economic conditions, types and costs of financing, and his own costs, as well as the conditions he will face in respect to markets, volume of business, terms of suppliers, and possible emergencies. In. addition, a carefully considered credit policy, close control of inventories, controlled use of labor and other factors of production or operation may reduce his ultimate need for financing.

He must be sure that his expansion means progress and not simply acceleration

*Ph.B., 1929, University of Chicago. Research Staff, Committee for Economic Devclopment; Treasurer, Phoenix Finance Corporation; Director, Consolidated Acceptance Company; member, American Economic Association; member, American Academy of Political and Social Science; contributor to Finance periodicals.

${ }^{2}$ From a speech before the Graduate School of Banking, American Bankers Association, at Rutgers University, New Brunswick, New Jersey, June 20, 1944. 
toward failure. When he goes to borrow he will find that the source he chooses looks carefully at management as an important factor in measuring security.

Obviously, the financing of small business must, for optimum results, be integrated with advice and guidance on management and financial policy. The businessman's problem is where to go for help along these lines both in the discovery of his needs and the elimination of weaknesses in the organization of his business.

The typical situation in which small business needs management aid as well as financing occurs when it is growing fast and encounters problems of administration which are not directly concerned with the familiar functions of buying, selling, or production. ${ }^{2}$ Such problems include: difficulties of departmentalizing; use of formal control data as contrasted with readily grasped daily experience; analysis of costs; controlling inventories; understanding the significance of budgeting to make the best use of all resources including funds; in short, changing from a business that one man keeps in his head to a more formal impersonal organization.

Another common.instance is the firm which has been declining in either profits or volume, or both. Somewhere along the line management is out of touch with reality and unable to recognize or cope with a puzzling situation.

Whether a firm is progressing and thus pressing against its ceiling of available funds, or declining and in search of ways and means for overcoming weak profits or deficits, the problem manifests itself to the proprietor as a need for money. In both cases, management guidance can make the difference between failure and success.

What often makes it difficult to extend financial assistance to small business is the failure to demonstrate that the product or service can be profitably marketed. The small business operator must be helped properly to present his case and show that study has been made along these lines. Then from the financial agencies' point of view, intelligent and sympathetic screening of such applications can be made.

In the case of businesses which show consistent profit and are well financed the tendency is to leave well enough alone and not seek outside management aid. The needed help is in policy decisions that will give direction to the firm's day-by-day activities and prevent the financial position from deteriorating. Of this character are improving budget methods, wage incentives, investigating alternative methods of distribution or financing, or securing perspective on one's own operation.

This type of aid is not sought to any extent when cost is prohibitive, when management is not made aware of what can be done, or where, as often happens, the absence of a need for funds gives no occasion for seeking advice or guidance.

Big business despite its own large resources makes extensive use of outside aid provided by the advertising agency, the independent auditor, the public relations

2 In a study by the National Opinion Research Center, University of Denver, a representative sample of small firms in all industries was asked, "What experience or training did you have for this business?" Only II.3 percent had had previous experience as owners or executives; the remainder, except for about I5 percent which had had no experience, had had experience as an employee, salesman, apprentice, or some education in the line of business. It can be presumed that financial experience was limited to a fraction of the II.3 percent which had indicated previous owner or executive background. 
counsel, and others who can dispel the inertia in a big operation. ${ }^{3}$ The small business needs help of an equally vital nature and would find itself better equipped to survive and expand if it could afford the outlay for management guidance.

The question of management aid is of particular interest during the war boom, when the loosest kind of management is successful in making a profit. In the firms established since 1939, many enterprises have arisen whose management has had only wartime experience. There are some manufacturers who have had no customer except the United States Government in their brief business career and whose managers have a background in production and not in financial administration.

It has been reported that 550,000 men in the Army alone have serious intentions of securing their own business after the war. ${ }^{4}$ Over half of the wage earners in Minnesota, according to a recent poll, would like to own their own business and are going to make some effort in that direction. ${ }^{5}$

Small business by its very nature-the low financial requirements, easy entry, attractiveness to the individual-invites entrants without management experience while it is usually unable to contain within itself the elements of good management in the way of accountants, financial experts, fact finding, and so on. The influx of new entrants, most without experience as managers, poses a very real problem in aiding deserving businesses to succeed in the postwar scramble.

Manufacturing as an industry presents greater hazards to the capital invested than do other business pursuits and false starts or management errors are as a rule more costly than the errors of judgment that pass in trade or service. (Although only one out of $x 8$ small businesses is in manufacturing, one out of 6 failures is in manufacturing.) The importance of manufacturing in providing both direct and indirect employment, the preoccupation of management with production and engineering, and the need for greater capital in manufacturing, have focussed more attention on its financial problems than on those of other segments of small business. It is no surprise, then, that much of the discussion today that refers to financial help and management aid to small business is actually in terms of the needs of the manufacturer.

To give the newer firms as well as new business entrants an opportunity to secure the benefit of more mature experience and to encourage these businessmen to seek it, some way must be devised to provide management aid on acceptable terms in proper form and on a continuing basis to all small business and especially to the small manufacturer.

Yet it must be kept in mind that the average small businessman is not keen about looking for or accepting outside management aid. He is not informed as to

\footnotetext{
${ }^{3}$ United States industry pays $\$ 65$ million per year which does not include outside lawyers, technical engineers, or accountants, for management aid. This is spent by healthy, not wcak, companics. This is because the business environment has grown so large and complicated. See Doctors of Mantgement (July, 1944) 30 FORTUNE 142.

'Army Service Forces, Soldiers' Plans to Own Businesses After They Leave the Army (Repntt No. B-130, Jan. 15, 1945, Information and Education Division, Hq. A. S. F.) I.

${ }^{\text {s }}$ Survey by the Minnesota Poll, Minneapolis Sunday Tribune, Feb. 18, 1945.
} 
the possibilities, he is usually not equipped to carry out in detail the broad recommendations of an adviser. He is suspicious of any device suggested by finance institutions which may possibly result in loss of control; he guards jealously his independence of action; he may resent the inference that he does not know all about his business; he has inordinate self-confidence, and often would rather go without funds than accept outside intervention. ${ }^{6}$

Some understanding of this aversion is to be found in the nature of the incentives that led him into business in the first place. In a recent survey the $\mathrm{Na}$ tional Opinion Research Center asked 600 representative small businessmen, "What is the main reason you went into business for yourself?" Personal ambition, expressed in a desire to create or to secure prestige or to expand beyond the job as an employee (these motives being apart from increase in earnings) accounted for 29.4 percent of all the answers. Dissatisfaction with job status and preference for independence formed the incentives for almost another third. These motivations reflect a laudable egotism which is not usually associated with receptivity to outside criticism or suggestion. It is of further interest that of the businessmen interviewed who indicated there had been factors which checked or slowed up the growth of their business, only slightly better than 8 percent blamed personal shortcomings. The war, too, because of the prosperity which has been almost universal with firms which carried on, has further served to increase the self-confidence of the small businessman.

Any proposal to improve small business management must indicate in what ways and from whom aid can be made acceptable.

Sources of Guidance. There are many ways in which small business has improvised aid for itself or has been proffered financial advice and guidance in an informal way. Advice and guidance has always been part of the lending business. Bank officers have laid claim, in view of their experience with other borrowers in the same business, to some expertness; but getting all the facts for decision is often expensive and beyond the return the bank can expect from a loan. Banks find themselves short of the kind of talent required for competent appraisal and handling of the applicant's problem.

It is the practice of well-managed banks, in making loans to newcomers in business, to talk over the various requirements of the projected enterprise; the discussion has often served as a screening process. They cannot take too much responsibility, however, for steering the prospective entrant because their advice cannot always be good and is likely to arise to plague them. Some of the advice they gave in the 'twenties embarrassed them in the depression 'thirties and from all indications, they do not wish to repeat the error on any scale. An increasing recognition

\footnotetext{
- This reluctance is illustrated by the experience of a large factoring firm in New York which recenty offered management aid to small business. It felt that many small businessmen could profitably use management counsel and gave considerable publicity to the establishment of such an advisory service at no charge. This was in October of 1944. As of March I, 1945, not a single case had been referred to this department.
} 
of the fact that guidance and financing must reinforce each other is reflected in a recent change of policy of the First National Bank of St. Paul. Previously, when a businessman made his third overdraft, he would be asked to leave the bank. Now the bank sends a junior officer to see the customer and carefully analyzes his diffculty with the idea of offering whatever help seems indicated.?

Industrial finance companies and factors, dealing with more marginal credits, found that keeping themselves adequately secured required almost week-to-week supervision and through the medium of this supervision, were providing considerable and usually constructive guidance.

Professional accounting service is another natural source; the accountant is perhaps the best qualified of any outsider who does not specialize in financial guidance. He has the obvious advantages which accrue to persons with an understanding of the records and their true meaning. The firm often looks to the accountant for budgeting. Yet sole dependence on the auditor has its shortcomings in that such items as marketing, sales relationships, purchasing policy and other technical functions which are not too often within the scope of an accountant's experience or interest.

The lawyer, too, has some qualifications as a financial adviser but like the accountant is limited in his grasp of the administrative problem. ${ }^{8}$

Trade associations have been an important source of information to a limited number of firms. The National Opinion Research Center in its inquiry learned that while only about a third of all businesses interviewed were members of a trade association (which did not include membership in general service organizations, such as Lions, Rotary, or Chambers of Commerce) nine out of ten of the third indicated that the benefit received was derived chiefly from the experience of others in discussion of mutual problems.

The Smaller War Plants Corporation as a wartime agency has been able to provide counseling services in connection with the placing of war contracts and encouraging war production. In the process of advancing money, leasing equipment, getting the full utilization of plant capacity, and providing engineering inspection, it was extending assistance to forestall financial difficulty. That assistance included finding war orders for the plant, checking for errors in pricing, guidance in meeting specifications, etc. Necessarily the SWPC participated in laying out the financial programs of the borrowers or lessees whom it assisted.9

\footnotetext{
${ }^{7}$ Cited by Richard Lilly, President. His bank has found that in 75 percent of the cases it was "not capital, but brains and management" that was needed.

${ }^{8}$ In Ir.I percent of the interviews made by National Opinion Research Center, University of Denver, the management indicated that they had outside professional advice on management problems. Almost 3 out of 5 of these referred to their trade associations or trade journals and another fourth consulted with their C.P.A. Of the 88.9 percent who did not use outside professional service for advice on management problems, only $I$ out of 16 had felt the need of such aid. However, over half of the firms interviewed used an outside accounting consultant, in most cases a C.P.A. On tax matters, over twothirds used, for the most part, a C.P.A. or attorney. In so far as C.P.A.'s or lawyers can give financial advice or guidance, it was available in a substantial majority of cases.

'By way of illustration, the following comes from "Ways Small Amounts of Capital Have Been Raised," a confidential report for the New England Industrial Council.

"Two men leave a large electrical company and obtain a subcontract of $\mathbf{\$ 2 5 0 , 0 0 0}$ through a Wash-
} 
In the great variety of term loans extended by the Reconstruction Finance Corporation, the problem occasionally arises of how far the federal agency should intervene in the management of the borrower. In the case of the RFC its powers are very broad, so that it has been able to participate in the construction and management of the projects it has sponsored.

The Federal Reserve bank under the I3-B Amendment to the Federal Reserve Act, have found that in extending term loans they must extend financial guidance as well. As an illustration, the case may be cited of one New England firm which turned to the Federal Reserve Bank for a direct loan after being denied by its regular bankers. Long overdue current liabilities indicated bankruptcy as the normal way out. The firm, however, accounted for a high percentage of the employment in the community and was, at the same time, engaged in important war production. The loan by the Federal Reserve Bank rendered possible the staying of bankruptcy proceedings. The granting of the loan by the Federal Reserve Bank was made contingent on acceptance of a financial rehabilitation program for the firm. Management was temporarily yielded by the owners to a new executive acceptable to the creditors; a strict system of budgeting was imposed; daily statements of operation were submitted to the Federal Reserve Bank, and the creditors were kept abreast of the progress of the firm under the reorganization. Situations of this sort can be met without much question during the period of war emergency. There are obvious disadvantages, however, to any large-scale assumption of control in management of small businesses by lending agencies as the price of financial support.

For the postwar period, the more generalized services of the Department of Commerce offer fruitful possibilities of expansion. Though it does not as a rule offer financial advice or guidance directly, the department's studies have provided the basis for improvements in market practice, industry control, budgeting and financing. Besides education in the form of books, monographs, and periodicals, the Department has made some personal contact available to businessmen through

ington connection. They know their business but they have no plant, equipment or raw material and practically no financial resources. They consider getting two or three men to finance them but feeling that they will have to take them in on a partnership basis, they decide that they would rather try to arrange financing in some other way and to keep the business for themselves. They apply at the Smaller War Plants Corporation for a loan and are financed to the extent of $\$ 25,000$ against the contract. After three months in which the company's operations are watched carefully by the Smaller War Plants Corporation they obtain a million dollar contract and receive additional credit from the Government agency. A still larger contract is obtained against shipments which are now running at an extremely high rate. The need for additional financing results in an arrangement for a revolving credit running up to $\$ 900,000$. The SWPC arranges for this loan by referring it to Washington.

"The company handles no money itself. Each month it sends its bills payable, payroll and other expense figures to the SWPC and the RFC and all the bills are paid by the Government agency. The managers have agreed to touch no money for the life of the contract. They also have agreed not to increase operating expenses to more than $\$ 271,000$ a month.

"Officials of the SWPC are very optimistic about the way the business is progressing, and they estimate that by the time the contract is fulfilled, these men will have paid for all their new and modern machinery and will have some working capital with which to conduct their business under peacetime conditions." 
its regional offices. Personal conference has necessarily been limited because of the size of the region covered, the large number of small businesses, and a staff inadequate to extend the full benefit of its information to potential users.

The veterans' program has inspired volunteers to supplement the federal services of the War Manpower Commission, such as committees of businessmen sponsored by business groups, chambers of commerce, banks, and local centers of the Committee for Economic Development. The need in this direction is only beginning to manifest itself so there is no experience by which to judge how effective these aids will be; but they do represent forerunners of more formal postwar types of financial and managerial counseling.

\section{II}

A number of committees have established financial guidance in the form of socalled industrial development corporations. Prominent among these are the Industrial Corporation of Baltimore, which has had a 25-year history; the Industrial Development Corporation of New England, ${ }^{10}$ and the Louisville Industrial Founda-. tion, Inc.

The Industrial Corporation of Baltimore determines the need for capital or credit and supplies, then negotiates for these. It handles industrial problems by means of management counsel and financial and technical services rendered on a professional basis. It limits its financing activity to firms needing $\$$ roo,000 or more, in the belief that those below that level are more in need of advice and counseling than funds. Though it makes an initial investigation without charge, it derives its income from fees and from commissions in connection with financing. The high minimum loan figure takes it out of the realm of an agency for small business, the greater part of which need loans for substantially smaller amounts. ${ }^{11}$ Nevertheless, the technique of making such medium-sized companies acceptable risks is an important one. The needed financial arrangement is coupled with managerial help ranging from reviews of the company's books to the drawing of long-term finance plans, making cost comparisons, developing new production programs, revising the relationship of stocks and volume of business, and even completely reorganizing the selling policies and systems.

The activities of the New England Industrial Development Corporation are discussed elsewhere in this symposium. ${ }^{12}$

The Louisville enterprise now limits its activity to extending credit. Its capital outlays are limited to first liens on plant and equipment. Though it affords semi-

${ }^{10}$ See infra, this symposium, Stoddard, A Regional Experiment in Practical Development of Industries, p. $36 \mathrm{r}$.

${ }^{11}$ National Opinion Research Center found that $2 x . I$ percent of the businesses intervicwed intended to borrow for reconversion or postwar expansion. Only $4 /$ to of one percent of all firms intervicwed wanted over $\$$ roo, 000 . These few were all manufacturers and constituted 1.6 percent of the manufacturers interviewed. Projecting this to the $\mathbf{1 6 8 , 0 0 0}$ small manufacturers in business (small are those employing 100 or less) there would be only about 2,700 small manufacturers in the nation who would be prospects for the service offered by the Industrial Corporation of Baltimore.

${ }^{12}$ Stoddard, supre note ro. 
fixed capital to industry, it does so to a very limited extent and only to firms which can offer substantial collateral. ${ }^{13}$

In January, I945, the Committee for Economic Development reported the formation of management aid projects of varying nature. In a New Jersey community a professional service committee consisting of lawyers, engineers, and other professional men was formed to give management counsel to small businesses. In Streator, Illinois, a management engineering company was formed on a community basis. Des Moines, Iowa, engaged an engineer to extend consultative aid. These are, however, all in the trial stage and it is much too early to comment either on the effectiveness or the exact nature of the plans. Publications of the CED are devoted to improving management planning and include handbooks on such diverse subjects as "Planning the Future of Your Business" (with separate issues for manufacturer, retailer, and wholesaler), "Selecting and Training Postwar Sales Personnel," "Markets After the War," "Handbook on Bank Credit," and others.

In evaluating the usefulness of the community and government aids which have been available, it would appear that service limited to giving advice has been less successful than advice coupled with financing. The supplying of funds and progressive promotion made Smaller War Plants Corporation more popular and useful than the less active but perhaps potentially more widely useful Department of Commerce which had no funds or contracts to attract inquiries. One of the weaknesses of the Industrial Development Corporation is a lack of sustained incentive in a civic organization. The use of the civically sponsored facilities is, in general, very sporadic. It is handled by a group of prominent citizens trying to be helpful and the small businessman is likely to shy away from exposing himself to his neighbors in that kind of setting.

Still to evolve is a form of industrial development corporation which can be sustained as a self-supporting private enterprise, with enough financial resources matching the size of problem that postwar expansion of small establishments demands.

Such a service to small business should have the following characteristics:

(x) It should preferably be local in character. (The differences between communities are important enough to require local experience, a knowledge of the community's assets and a wide friendly contact within the community, if its small establishments are to be served.)

(2) It should be able to secure the cooperation of all business elements of the community; it must reach all small business, not manufacturing alone.

(3) It must have direct access to funds; to permit the combining of guidance with financing where the situation requires.

\footnotetext{
${ }^{23}$ There have been other community industrial financing plans of which some 26 were reported by the U. S. Chamber of Commerce. Practically all of these would more accurately be described as community industrial bonus plans, as they were interested principally in making some form of direct or indirect subsidy to attract new or established manufacturers to their community.
} 
(4) It should be concerned with the businessman as a client, rather than as a problem for community aid.

(5) It should encourage the establishment of needed technical facilities adapted to the requirements of the small establishment.

(6) It should be self-supporting, but it should aim to develop a low-cost service. This may involve pooling of specialized counsel with similar organizations.

(7) It should promote the willingness of investors in the community to find outlets for their funds among local small businesses.

(8) It should avoid mergers or alliances tending to restrict competition by local businessmen.

The privately operated agency catering to the management and financing requirements of the small business cannot properly concern itself with the great mass of very small establishments, including more than a million self-employed which have no employees except for members of their own family. Yet this is an area in which there is much to be done in eliminating the waste of inefficiency and the reduction in the number of ill-conceived ventures. The personal loan department of local banks and the small finance companies have carried on a certain amount of guidance work in connection with the granting or refusal of loans to these oneman establishments. To a lesser, yet important, degree, the ordinary commercial credit department of supplier firms has helped small customers to avoid embarrassing commitments. A strong case can be made for the proposition that the waste of new ventures for which inadequate preparation has been made and for which inadequate management-aid exists, constitutes a problem affecting the soundness of the economy as a whole. In that sense, the improvement of small business management is a public concern. It is not enough for government departments to publish literature about which the alert small businessman will find out. In the common interest, it is desirable that an agency of government extend the present activities of the Department of Commerce to promote periodic interviewing service among small businesses. This would probably start out as an elaboration of the Business Census, to uncover the problems of small business to which attention must be given. This type of census-taking can be a forerunner of a more intimate relationship between the individual businessman and district offices of the government agency. The district office can perform an important service in steering the small businessman to financial aid or technical services not known to him; it may at the same time initiate him in the use of the information regarding markets, standards of performance, patents, and commodity testing, all of which may contribute to the improvement of efficiency in the small business. The relatively small influence of the federal guidance of small business in the prewar period, as compared with the amount of effort that the federal government has put into the gathering of business information, suggests a re-examination of the possibilities for government to be more directly useful in the education of the small businessman. 
A relatively untapped resource for the guidance of small business and its financial and managerial problems is the collegiate school of business. Those charged with higher education in the field of business are belatedly becoming aware of the fact that the traditional business education program has focused on the acquisition of professional competence in a special department of business. The schools have turned out accountants, credit men, statisticians, office managers. But, it has given negligible attention to preparation for the operation of a small business or to the re-education of businessmen who could profit by better understanding of the problems of financial administration. In the opinion of those contemplating the establishment of such courses or clinics, the greatest difficulty lies in obtaining men with the necessary experience as well as technical competence who would be willing to devote themselves to teaching in that field. A more readily soluble problem is that of supplementing the teaching program of the collegiate schools of business with a program of research and the feeding in of literature dealing concretely with the day-to-day problems which the small businessman must meet.

There is little question that small business in general tends to lose out because of unfamiliarity with the techniques of sound management. This applies not only to an appreciation of what constitutes sound financing, cost accounting, and record keeping in general, but to technical efficiency in production and distribution and product development through research. Small business has very little idea of how general business conditions and the character of the total market to which it belongs affects its own individual operations.

Even though small businesses which are aware of these problems are prone to feel-with some justice-that they do not have the financial resources with which to fortify themselves adequately in this regard, small business needs access to such facilities. If means can be created to improve the management of the smaller enterprise and which will also make and maintain a live contact with the small businessman rather than wait until the small businessman is in distress, an important differential handicap of small business will be eliminated.

Community service organizations working in full co-operation with a federal agency for the more general educational services, and with collegiate schools of business, may effectively supplement the incidental guidance activities of the banks and other lending agencies. 